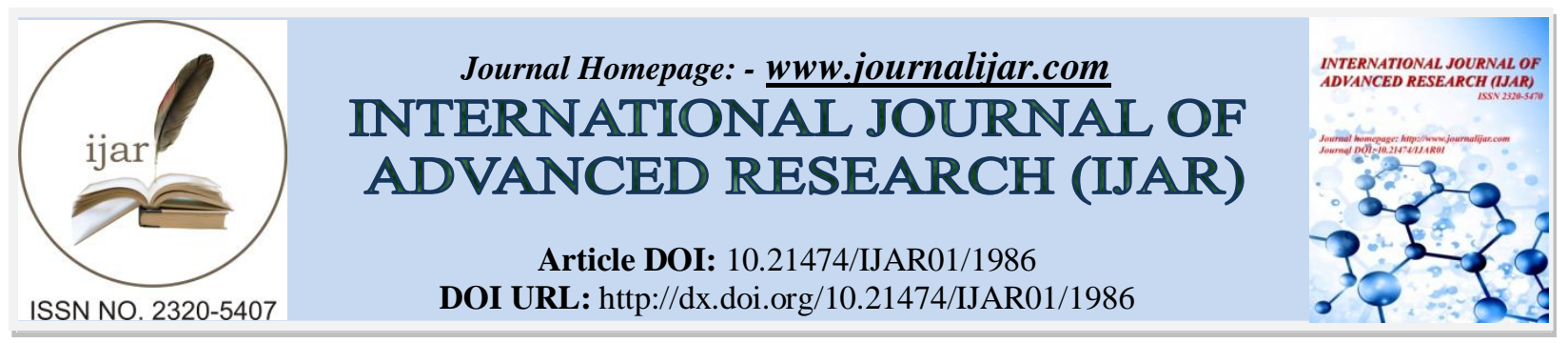

RESEARCH ARTICLE

\title{
BOTANICAL PESTICIDES: AN UPCOMING TOOL FOR PLANT PROTECTION.
}

Meena Khetrapal ${ }^{1}$ and Lata Vodwal ${ }^{2}$.

1. Department of Chemistry, Daulat Ram College, University of Delhi, Delhi, India.

2. Department of Chemistry, Maitreyi College, University of Delhi, Delhi, India.

\section{Manuscript Info}

Manuscript History

Received: 12 August 2016

Final Accepted: 13 September 2016

Published: October 2016

Key words:-

Botanicals, Conventional pesticides,

Environmental hazards and Natural enemies.

\section{Abstract}

Over the years, heavy reliance on conventional synthetic pesticides in the cultivation of crops has led to several unforeseen environmental problems such as rapid development of resistance in pests, suppression of parasitoids, predation, increased insect outbreaks, environmental and food chain contamination. To avoid all the demerits of chemicals used as commercial pesticides, an integrated strategy for crop pest control which includes biological control and chemical pesticides including "Botanicals" needs to be developed. So, extensive studies have been carried out on the use of plant derivatives both as crude preparations and as commercial formulations against the control of pest population without affecting their natural enemies.

Copy Right, IJAR, 2016,. All rights reserved.

\section{Introduction:-}

By considering the continuing rapid increase with the rate of world population and the further decreasing rate of world lands, it is necessary to produce more and more economic crops in order to balance the economy of our country ${ }^{1}$. It has been quantified that with current pest control technologies, yields are 30-35\% less on an average, than they would be in the absence of pests. Pests are organisms which not only cause quantitative losses, but also affect the quality of agricultural product which may become noticeable through deterioration of taste, fibre strength, processing characteristics, seed germination, etc. It has been found that about 2.5 million tons of pesticides are used to eradicate the pest population each year and the worldwide loss caused by these pesticides reaches $\$ 100$ billion annually. This happens due to the non-biodegradable and high toxic properties of these conventional pesticides which are also left as residues in soil, crops and water resources that directly or indirectly affect the public health.

The long term negative effects of using pesticides did not begin to surface until 1950s. In the year 1962, Rachel Carson's book 'silent spring' provided the general public with the first warning that many pesticides produce undesirable side-effects on our environment ${ }^{2}$. Further consequences of over-reliance on pesticides became apparent over the next few decades. For example, prior to 1940s, it was estimated that insects destroyed 7\% of the worlds, crops; by the late $1980 \mathrm{~s}$, crop destruction due to pests had arisen to $13 \%$. This doubling of crop damage since the pesticides revolution occurred despite a 12-fold increase in pesticides use ${ }^{3}$. The increase in crop destruction is due, in part, to increased incidence of "secondary pest out breaks", "pesticides resistance" and "natural enemy destruction". These problems, coupled with increasing environmental concern and pesticides costs, have forced growers to seek more environmentally safe and cost-effective pest control strategies. Thus, on one hand, one needs to search the new, highly selective and biodegradable components to rectify the problem of long term exposure of mammals to toxic chemicals; on the other hand, one must develop the, 'eco-safe' pesticides and also improve the techniques which help to minimise the use of commercial pesticides for maintaining the crop yields. In this regard,

Address:- Department of Chemistry, Maitreyi College, University of Delhi, Delhi, India. 
the natural products (secondary metabolites) are found to be an excellent alternative to conventional synthetic pesticides as in this way, one can reduce the negative impact of pesticides on human health and on the environment. So, a move toward the approach of green chemistry and the continuing need for developing new crop protection tools with novel modes of action makes discovery and commercialization of natural products as "green pesticides" an attractive and profitable pursuit that is commanding attention. The concept of "green pesticides" refers to all types of nature-oriented components that are used to control the population of pests and ultimately increase the food production. These green pesticides are 'safe or eco-friendly' and are also found to be more compatible with the environmental components than the synthetic pesticides ${ }^{4}$.

\section{Introducing Botanical Pesticides as Green Pesticides:-}

All plants produce secondary metabolites that are phytotoxic to some degree and most of them are used as botanical pesticides. Extensive studies have been carried out on the use of these plant products both in the crude as well as commercial formulations against several pests without affecting their any natural enemies ${ }^{5}$. A large number of bioactive phytochemicals (Table 1) isolated from diverse sources are now known which have not only provided leads to the discovery of new pesticidal molecules, but have also helped in proper understanding of their mode of action. Commercial products based on Azadirachta Indica (neem) are known to affect more than 400 species of insects, mites, nematodes and fungi. Other traditionally insecticidal plants like Media, Chrysanthemum, Derris, Nicotiana, Tephrosia, Ryania, Sabadilla Annona, etc., have also earned world wide attention ${ }^{6}$.

Table 1:- Appropriate botanical pesticides use.

\begin{tabular}{|l|l|l|}
\hline S. No. & \multicolumn{1}{|c|}{ Botanical Pesticides } & \multicolumn{1}{c|}{ Use Against } \\
\hline 1 & Pyrethrum $^{7} /$ Nicotine $^{8}$ & $\begin{array}{l}\text { Pickleworms, spider mites, aphids, cabbageworms, leafhoppers, } \\
\text { harlequin bugs, Mexican bean beetles, flea beetles, squash bugs, flies, } \\
\text { etc. }\end{array}$ \\
\hline 2 & Rotenone $^{9}$ & $\begin{array}{l}\text { Mexican bean beetle, colorado potato beetle, japanese beetle, fleas, flea } \\
\text { beetles, spittlebugs, cucumber beetles, aphids, carpenter ants, potato } \\
\text { beetles, mites, loopers, cabbage worms, etc. }\end{array}$ \\
\hline 3 & Ryanoidine $^{10}$ & $\begin{array}{l}\text { Codling moths, oriental fruit moth, corn earworm, potato aphid, thrips, } \\
\text { onion, etc. }\end{array}$ \\
\hline 4 & Sabadilla $^{11}$ & $\begin{array}{l}\text { Armyworms, stink bugs, hariequin bugs, leafhoppers, cucumber beetles, } \\
\text { blister beetles, cabbage loopers, etc. }\end{array}$ \\
\hline
\end{tabular}

Several other plants like piper, capsicum, ginger, turmeric, etc. better known for their edible properties also exhibited a wide range of pest control properties including fecundity, phagodeterrent oviposion deterrent and growth disrupting effects.

The botanical pesticides are processed into various forms which include:-

- $\quad$ Preparation of crude plant material;

- Plant extracts or resins; and

- Pure chemical isolated from plants.

\section{Botanical Insecticides- First to Fourth Generation Insecticide:-}

The "first generation" insecticides referred as "botanicals", include plant extracts and plant secondary metabolites, such as nicotine, pyrethrum, rotenone, derris, quassin and sabadilla. Some of these botanical compounds form the foundation for the synthetic "second generation" pesticides. For example, pyrethrum isolated from Chrysanthemum flowers has become the basic unit for the synthetic pyrethroids and physostigmine from Physostigma venenosa has lead to the structurally similar synthetic carbamates. These "second generation" pesticides mostly are nerve poisons and affect not only the target pest but also the non target pest. But, there is no question that industries have helped to control he pest, in part time but the extreme and with this same reason in last two decades people moved away from the "second generation" synthetic pesticides. "Third generation" pesticides focused on insect growth regulators such as precocenes and phytoecdysones. The third generation pesticides are assumed to be more selective and environmentally safe; they usually work slowly and are not able to prevent insects from destroying a bulk amount of crop before dying. The "fourth generation" or "next" of pesticides depend upon the behavior modifying compounds like antifeedant and deterrents. 


\section{Botanical Pesticides as Olfactory Chemicals:-}

Olfactory chemicals (Table 2) are usually essential oils with relatively high vapor pressure and are used to control the insect population at olfactory level. On the basis of movement and orientation towards or away from the source, they are designated as attractant or repellents or antifeedants.

Table 2:- Olfactory chemicals and their use as botanical pesticides.

\begin{tabular}{|c|c|c|}
\hline S. No & Nature & Olfactory Chemicals \\
\hline \multirow[t]{2}{*}{1.} & \multirow[t]{2}{*}{ Attractants $^{12}$} & $\begin{array}{l}\text { Eugeno compound isolated from Eugenia aronatica, used as an attractant to control } \\
\text { the population of fruit fly Dacus dorsalis in orchards. }\end{array}$ \\
\hline & & $\begin{array}{l}\text { Terpenoids isolated from flowers of Catasetum cynoches and Stenopia elicited } \\
\text { excited behaviour in male of Euglossa bees similar to the effect of sex attractant. }\end{array}$ \\
\hline \multirow[t]{6}{*}{2.} & \multirow[t]{6}{*}{ Repellents $^{13}$} & Oil of Citronella $s p$, used as mosquito repellent. \\
\hline & & $\begin{array}{l}\text { Geraniol isolated from Hemisonia fitche is used as a repellent against Aedes aegyptii } \\
\text { (yellow fever mosquito). }\end{array}$ \\
\hline & & $\begin{array}{l}\text { Lignins isolated from the roots of Piper capensis proved to be a repellent against } \\
\text { ants. }\end{array}$ \\
\hline & & $\begin{array}{l}\text { Pyrethrum extract (5\%) in combination with 5-10\% cotton seed oil emulsified with } \\
\text { blood albumin shows high repellent properties against full codling moth larvae. }\end{array}$ \\
\hline & & Neem seed extracts used as repellents against Spodoptera litura. \\
\hline & & $\begin{array}{l}\text { Curcuma longa (essential oil) showing repellent properties against Rhizopertha } \\
\text { dominica. }\end{array}$ \\
\hline 3. & Antifeedant $^{14}$ & $\begin{array}{l}\text { Limonoid Azadirachtin is a phytochemical isolated from Azadirachta indica and } \\
\text { used as antifeedant. }\end{array}$ \\
\hline
\end{tabular}

\section{Specific Compounds with Significant Biological Activity:-}

Flowers, leaves or roots may be directly used as botanical pesticides (Table 3) in their powdered form or the bioactive compound may be extracted from the plants and utilized alone or in a mixtures with other toxicants and auxiliary materials to control the pest population. Plant gums are used as adhesives, saponins have spreading and emulsifying properties and essential oils are frequently attractive or repellent to insects.

Table 3:- List of selected botanical pesticides and their mode of action against pests ${ }^{15}$.

\begin{tabular}{|l|l|c|c|l|}
\hline \multicolumn{1}{|c|}{ CHEMICALS } & \multicolumn{1}{c|}{ CLASS } & ORAL LD $_{\mathbf{5 0}}$ & DERMAL LD $_{\mathbf{5 0}}$ & \multicolumn{1}{c|}{ MODE OF ACTION } \\
\hline Bifenthrin & Pyrethroid & 632 & $>2,000$ & Contact \& stomach activity \\
\hline Cyfluthrin & Pyrethroid & $960-1,150$ & $>2,000$ & Contact \& stomach activity \\
\hline d-Limonene & Botanical & $>5,000$ & -- & Contact poison \\
\hline Horticulture oil & Oil & 5,000 & -- & Contact \& stomach activity \\
\hline Imidacloprid & Neonicotinyl & $1,858-2,591$ & $>2,000$ & Contact \& stomach activity \\
\hline Linalool & Botanical & $2,440-3,180$ & $3,578-8,374$ & Contact poison \\
\hline Neem & Botanical & 13,000 & -- & Insect growth regulator \\
\hline Nicotine & Botanical & $50-60$ & 50 & Contact poison \\
\hline Permethrin & Pyrethroid & $430-4,000$ & $>2,000$ & Contact \& stomach activity \\
\hline Pyrethrins & Botanical & $1,200-1,500$ & $>1,800$ & Contact activity \\
\hline
\end{tabular}

These botanicals are useful as insecticides and may be classified as follows:

a. Nicotine:-

- Source: it is a simple alkaloid derived from tobacco leaves, Nictiana tabacum and other Nicotiana rustica (Family: Solanaceae).

- Mode of action: nerve toxin.

- Use against: thrips, aphids, caterpillars.

- Chemistry: 
IUPAC NAME: $\quad(S)$-3-[1-Methylpyrrolidin-2-yl]pyridine

Formula:

$\mathrm{C}_{10} \mathrm{H}_{14} \mathrm{~N}_{2}$

Trade names:

Boiling point:

Nicorette, Nicotrol

Specific gravity:

Solubility:

$247.3{ }^{\circ} \mathrm{C}$

$1.0093 \mathrm{~g} / \mathrm{cm}^{3}$

Soluble in water as well as in alcohol, ether, chloroform \& petroleum oil.

Activity:

Insecticides (botanical insecticides)

Structure:

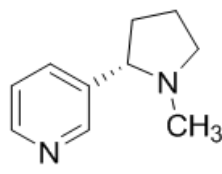

Nicotine

b. Nornicotine:-

- Source: it is a liquid alkaloid obtained from Nicotiana sylvestris (Family: Solanaceae).

- Mode of action: nerve toxin

- Use against: Aphis fabae Scop, Myzus persicae, etc.

- Chemistry: its structure resembles that of nicotine.

IUPAC NAME: $\quad$ (S)-3-(1-pyrrolidin-2-yl) pyridine

Formula:

$\mathrm{C}_{9} \mathrm{H}_{12} \mathrm{~N}_{2}$

Sp.gr.:

$1.07 \mathrm{~g} / \mathrm{cm}^{3}$

Boling point:

$270-271{ }^{\circ} \mathrm{C}$.

Solubility:

Activity:

Soluble in water and organic solvents.

Structure:

Insecticide (botanical insecticide)<smiles>c1cncc([C@@H]2CCCN2)c1</smiles>

\section{Nornicotine}

c. Anabasine:-

- Source: it is a liquid alkaloid obtained from Nicotiana glauca (Family: Solanaceae).

- Mode of action: nerve toxin

- Use against: Aphis fabae, codling moth larvae, guinea pigs and rabbits etc.

- Chemistry:

IUPAC NAME:

Formula:

Sp.gr.:

Boling point:

Solubility:

Activity:

Structure:

(S)-3-(2-piperidyl) pyridine

$\mathrm{C}_{10} \mathrm{H}_{14} \mathrm{~N}_{2}$

$1.0481 \mathrm{~g} / \mathrm{cm}^{3}$

280- $282{ }^{\circ} \mathrm{C}$.

Soluble in water and organic solvents

Insecticide (botanical insecticide)<smiles>c1cncc([C@H]2CCCCN2)c1</smiles>

Anabasin 


\section{d. Azadirachtin:-}

- Source: it belongs to limonoids group and isolated from Neem tree. (Azadirachta indica; Family: Meliaceae).

- Mode of action: repellent, antifeedant and reproduction inhibition.

- Use against: insects belonging to order Coleopteran, Diptera, Heteroptera, omoptera, Hymenoptera, Lepidoptera and Orthoptera.

e. Pyrethrum and Pyrethrins:-

- Source: it is an organic compounds isolated from dried flower head of the (Chrysanthemum cinerariaefolium; Family: Asteraceae). Pyrethrins (Table 4) are gradually substituting the demand of organophosphates and organohloride pesticides.

- Mode of action: interferes with the $\mathrm{Na}^{+}$and $\mathrm{K}^{+}$exchange process in insect nerve fibers and also disturbs the normal transmission of their nerve impulses.

- Use against: aphids, beetles, mealy bugs. leafhoppers, thrips, cabbage worms, loppers and many others.

- Chemistry: the pyrethrins are naturally occurring esters formed as a result of combination of two acids: pyrethric acid and chrysanthemic acid with three alcohols. The pyrethrins are known for its knockdown and toxicity properties.

Table 4:- List of pyrithrins and their chemical structure.

\begin{tabular}{|l|l|l|l|}
\hline S. & Chemical & \\
No. & Compounds & Pyrethrin I & \\
\hline 1. & Cinerin I & & \\
\hline 3. & Jasmolin I & Pyrethrin II &
\end{tabular}




\section{f. Rotenone:-}

- Source: it is a ketonic derived organic compound isolated from roots of Lonchocarpus species (Family: Fabaceae).

- Mode of action: inhibits the cellular respiration is acricidal (mite and spider-killing) and piscicidal (fish killing)

- Use against: Bombyx mori, Aphis fabae, Apis mellifera, etc.

- Chemistry:

Formula:

Sp.gr.:

Boling point:

Solubility:

Activity:

Structure:
$\mathrm{C}_{23} \mathrm{H}_{22} \mathrm{O}_{6}$ $1.27 \mathrm{~g} / \mathrm{cm}^{3}$ $280-282{ }^{\circ} \mathrm{C}$.

Soluble in non-polar organic solvents Insecticide (botanical insecticide)<smiles>C=C(C)[C@H]1Cc2c(ccc3c2OC2COc4cc(OC)c(OC)cc4[C@H]2C3=O)O1</smiles>

\section{g. Limomnen:-}

- Source: it is a liquid hydrocarbon isolated from citrus fruits (Family: Rutaceae).

- Mode of action: it affects peripheral nervous system.

- Use against: fleas, lice, mites and ticks.<smiles>C=C(C)C1CC=C(C)CC1</smiles>

h. Sabadilla alkaloids:-

\section{Limomnen}

- Source: it belongs to veratrine alkaloid obtained from ripe seeds of Schoenocaulon officinale (Family: Melanthiaceae).

- Mode of action: affects the nervous system which leads to paralysis and death.

- Use against: caterpillars of leafhoppers, thrips, stink bugs, squash bugs, grasshoppers, cabbage loopers, moths, armyworms, aphids, blister beetles, squash bugs, codling moths, and harlequin bugs.

\section{i. Ryanoidine:-}

- Source: it is an alkaloid and isolated from woody stems of Ryania speciosa (Family; Salicaceae).

- Mode of action: it causes muscular contractions and paralysis.

- Use against: codling moths, japanese beetles, potato aphids, squash bugs, corn earworms, onion thrips and silkworms.

\section{Conclusions:-}

Heavy dependency on commercially available synthetic pesticides in the field of agriculture, over the years, has had a bad impact on environment and has lead to several problems like the increased tendency to developed the resistance in pests, increased insect outbreaks, suppression of predation and parasitoids and contamination of the food chain. But later on, because of the environmental hazards of random use of pesticides, the new generation of pesticides have emerged in the field i.e. "Botanicals" and "Green pesticides". 
Finally, greening of environmental-pesticidal interactions, improving pest specificity, lower persistence and, less non-target toxicity has reduced the use of conventional pesticides.

\section{References:-}

1. Casida JE. (2000): Pest toxicology: the primary mechanisms of pesticide action. Chem Res Toxicol., 22:609619.

2. Carson R. (1962): Silent Spring. Boston: Houghton Miffli.

3. Tomlin CDS. (2009): The Pesticide Manual: A World Compendium. $15^{\text {th }}$ ed. Alton, UK: British Crop Production Council.

4. Isman MB and Machial CM (2006): Pesticides based on plant essential oils: from traditional practice to commercialization. In M. Rai and M.C. Carpinella (eds.), Naturally Occurring Bioactive Compounds, Elsevier, BV, pp 29-44.

5. Koul O (1995): Acorus allelochemical: Chemistry and bioefficacy against insects. In B.S. Parmar and S Walia (eds.), Pesticides, Crop Protection and Environment, Oxford and IBH Publishing Co. Pvt. Ltd., New Delhi, pp. 99-113.

6. Koul O, Dhaliwal GS, Marwaha SS and Arora JK (2003): Future perspectives in biopesticides. In O Koul, GS Dhaliwal, SS Marwaha and JK Arora (eds.), Biopesticides and Pest Management., Vol.1, Campus Books International, New Delhi, pp. 386-388.

7. Elliott M (1977): Synthetic insecticides from the natural pyrethrins. In: Natural Products and the Protection of Plants (Ed. Marini-Bettolo, G.B.), pp. 157-176. Pontificia Academia Scientiarvm, Citta del Vaticano.

8. Ujváry István (1999): "Nicotine and Other Insecticidal Alkaloids". In Yamamoto Izuru; Casida John. Nicotinoid Insecticides and the Nicotinic Acetylcholine Receptor. Tokyo: Springer-Verlag. pp. 29-69.

9. Ambrose, Anthony M, Harvey BH (1936): "Toxicological study of Derris". Industrial \& Engineering Chemistry 28 (7): 815-821.

10. Isaacs AK, Qi S, Sarpong R, Casida JE (2012): Chem Res Toxicol., 25(8):1571-3.

11. California Environmental Protection Agency (2001): Summary of Toxicology Data: Sabadilla Alkaloids. Department of Pesticide Regulation, Medical Toxicology Branch.

12. Hammack L (1996): Corn volatiles as attractants for northern and western corn rootworm beetles (Coleopteran: Chrysomelidae: Diabrotica sp.). J. Chem.Ecol., 22:1237-1253.

13. Inazuka S (1983): Monoterpenoids as repellents against the German cockroach (Blattela germanica L.). J. Pestic. Sci., 8:293-299.

14. Chandravadana MV (1987): Identification of triterpenoid feeding deterrent of red pumpkin beetles (Aulacophora foveicollis) from Momordica charantia Journal Chemical Ecology 13, 1689-19643.

15. Henn and Rick W (1989): Alternatives in Insect Management: Botanical Insecticides and Insecticidal Soaps. University of Illinois CES, circular 1296, p. 6. 